\title{
[O-T-013] EFFICIENT SECRETION OF BIOENGINEERED COAGULATION FACTOR VIII INTO THE MILK OF TRANSGENIC ANIMALS
}

\author{
S.W. Pipe, H.Z. Miao, S.T. Butler, R.J. Kaufman, J. Calcaterra, W.H. Velander. Pediatrics, \\ University of Michigan, Ann Arbor, MI; Biomedical and Engineering Sciences, Virginia Tech, \\ Blacksburg, VA; Biological Chemistry and Howard Hughes Medical Institute, University of \\ Michigan, Ann Arbor, MI; Chemical and Biomedical Engineering, University of Nebraska, \\ Lincoln, NB, United States
}

Introduction: Recombinant factor VIII (rFVIII) is presently produced and purified from mammalian cell lines in liquid culture but has proven to be costly. The milk of transgenic livestock can yield an abundant source of complex therapeutic proteins. While properly processed recombinant factor IX and protein $\mathrm{C}$ have been produced at levels up to $100 \mathrm{U} / \mathrm{ml}$ in the milk of transgenic pigs, levels of full length rFVIII were $<1 \mathrm{U} / \mathrm{ml}$, likely due to secretory inefficiency, chain dissociation and proteolytic degradation.

Methods: Transgenic mice provide both insight into the encoding fidelity of the transgene constructions as generally expressed by mammary epithelia and useful amounts of posttranslationally modified, recombinant protein for evaluation. A rFVIII variant bioengineered for enhanced secretion (F309S/226aa/N6) was expressed in the milk of transgenic mice using the $4.2 \mathrm{~Kb}$ murine Whey Acidic Milk Protein (mWAP) 5'-promoter \& 1.3 kb of mWAP 3'-UTR elements. Transgenic mice were made containing F309S/226aa/N6 in combination with von Willebrand factor (vWF) and/or alpha1-antitrypsin (AAT) to help stabilize the rFVIII and reduce proteolytic degradation.

Results: Pronuclear injection of equimolar mixtures of the transgenes was used to produce multigenic mice. 18 founder lineages were outbred with wild-type mice. Milk from F1 lineages was screened for rFVIII by ELISA; 0 of 4 F1 lineages bigenic for FVIII\&vWF expressed FVIII, 2 of 6 F1 lineages bigenic for FVIII\&AAT expressed rFVIII at a range of 1-11 ug/ml, while 1 of 4 F1 trigenic lineages expressed rFVIII at $61 \mathrm{ug} / \mathrm{ml}$. Western blots showed primarily intact rFVIII that quantitatively agreed with ELISA results. Only the milk of the trigenic FVIII-AAT-vWF mice showed high level coagulation activity (34 U/ml).

Conclusions: Very high level rFVIII milk-specific expression can be achieved using high secretion efficiency FVIII variants when co-expressed with vWF and AAT. This multi-gene strategy is being studied in cloned transgenic pigs.

Pipe SW, Miao HZ, Butler ST, Kaufman RJ, Calcaterra J, Velander WH. EFFICIENT SECRETION OF BIOENGINEERED COAGULATION FACTOR VIII INTO THE MILK OF TRANSGENIC ANIMALS. $J$ Thromb Haemost 2007; 5 Supplement 2: O-T-013

Date: Tuesday, July 10, 2007

Session Info: Oral Communications: Haemophilia and therapy

Room: Room A/B 